\title{
COLLEGE STUDENTS' PHYSICAL AND MENTAL HEALTH EXERCISE BASED ON TENNIS
}

EXERCÍCIO DE SAÚDEFISICA EMENTAL DE ESTUDANTES COM BASENO TÊNIS

EJERCICIOS DE SALUD FISICA Y MENTAL PARA ESTUDIANTES UNIVERSITARIOS BASADOS EN EL TENIS

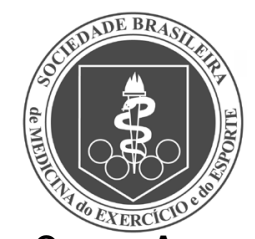

Original Article

ARTIGO ORIGINAL

Artículo Original
Yan Li' (ID

(Public health Education)

1. Guilin University of Aerospace Technology, Guilin, Guangxi, China.

\section{Correspondence:}

Guilin, Guangxi, China.

dstald@163.com

\begin{abstract}
College students are often under great pressure, and their physical and mental health is the focus of attention in college education. In order to cultivate high-quality talents and relieve the pressure of college students, many colleges and universities have set up a variety of sports courses, including tennis courses. Analyzing the influence of tennis on the physical and mental health of college students, this study studies the situation of college students participating in tennis by consulting literature, designing questionnaires and using an experimental measurement method, while it constructs the physical health evaluation index and mental health evaluation index of college students. On this basis, this study evaluates the influence of tennis on students' physical and mental health. The results show that tennis has a positive impact on the physical and mental health of college students. Tennis can not only enhance college students' cardiopulmonary function and muscle strength, but also cultivate students' independent personality, eliminate depression tendency, make students independent, flexible and active, which is conducive to the development of students' mental health. It is hoped that this study can provide some reference for the research of college students' physical and mental health exercise based on tennis.
\end{abstract}

Keywords: Tennis; sports; colleges and universities; students; physical and mental health

\section{RESUMO}

Los estudiantes universitarios a menudo se encuentran bajo una gran presión y su salud física y mental es el centro de atención en la educación universitaria. Para cultivar talentos de alta calidad y aliviar la presión de los estudiantes universitarios, muchos colegios y universidades han establecido una variedad de cursos deportivos, incluidos cursos de tenis. Al analizar la influencia del tenis en la salud fisica y mental de los estudiantes universitarios, este estudio considera la situación de los estudiantes universitario que participan en el tenis. Para ello us a la consulta de literatura, el diseño de cuestionarios y un método de medición experimental para construir el índice de evaluación de la salud física y la salud mental. Sobre esta base, este estudio evalúa la influencia del tenis en la salud física y mental de los estudiantes. Los resultados muestran que el tenis tiene un impacto positivo en la salud física y mental de los estudiantes universitarios. El tenis no solo puede mejorar la función cardiopulmonar y la fuerza muscular de los estudiantes universitarios, sino también cultivar la personalidad independiente de los estudiantes, eliminar la tendencia a la depresión, hacer que los estudiantes sean independientes, flexibles y activos, lo que favorece el desarrollo de la salud mental de los estudiantes. Se espera que este estudio pueda proporcionar alguna referencia para la investigación del ejercicio de salud física y mental de estudiantes universitarios basado en el tenis.

Descritores: Tênis; esporte; faculdades e universidades; estudantes; saúde física e mental.

\section{RESUMEN}

Estudantes universitários estão frequentemente sob grande pressão, e sua saúde física emental éo foco da atenção na educação universitária. A fim de cultivar talentos de alta qualidade e aliviar a pressão dos estudantes universitários, muitas faculdades e universidades criaram diversos cursos de esporte, incluindo cursos de tênis. Analisando a influência do tênis na saúde física e mental dos estudantes universitários, este estudo investiga a situação dos estudantes universitários que praticam tênis através de consultas de literatura, elaboração de questionário e do método de medição experimental, enquanto constrói o índice de avaliação da saúde física e da saúde mental de avaliação dos estudantes universitários. Nesta base, o estudo avalia a influência do tênis na saúde física e mental dos estudantes. Os resultados mostram que o tênis tem um impacto positivo na saúde física e mental dos estudantes universitários. O tênis pode não só aumentar a função cardiopulmonar e a força muscular dos estudantes universitários, mas também cultivar a personalidade independente dos estudantes, eliminar a tendência de depressão, torna-los alunos independentes, flexíveis e ativos, o que favorece o desenvolvimento da saúde mental dos estudantes. Espera-se que este estudo possa fornecer alguma referência para a pesquisa do exercício de saúde física emental dos estudantes universitários com base no tênis.

Descriptores: tenis; deportes; educación superior; estudiantes; salud fisica y mental. 


\section{INTRODUCTION}

With the accelerated pace of social life and the increasingly fierce social competition, people's life pressure is increasing, which has caused many physical and mental health problems.' In such a fast-paced, high-pressure and high-risk era, college students, as a part of the society, are the best of their peers. They often carry a lot of expectations and concerns from society, school and family, so they also bear great pressure from themselves and the surrounding environment. This pressure leads to different degrees of physical and mental health problems of college students Such as nervous tension, poor sleep quality, interpersonal sensitivity and anxiety and depression. ${ }^{2}$ As a common way to exercise and relieve pressure, exercise has always been the materialization of human survival spirit, and it is also an important way for human beings to challenge themselves. As a way of sports, tennis can also have a variety of beneficial effects on the human body. It can not only enhance people's physical function, but also exercise people's mental health. It has antagonism, interest and diversity of skills, so it is popular among college students. ${ }^{3}$ The physical and mental health education of college students is an urgent requirement to comprehensively promote quality education and cultivate high-quality talents. It is conducive to the positive development of College Students'body and mind to include the physical and mental health education into university education ${ }^{4}$ High quality talents need not only good scientific and cultural quality, ideological and moral quality and physical health quality, but also good psychological quality. As the cradle of cultivating high-quality talents, colleges and universities have the responsibility and obligation to cultivate students with healthy physical and psychological development. ${ }^{5}$ At present, in order to implement quality education, many colleges and universities have carried out various sports teaching, among which tennis course is an important course, and tennis course is being pursued by more and more college students. Tennis can have a positive impact on College Students' physical and mental health, so this study analyzes the impact of tennis on College Students' physical and mental health.

It can be seen that the research at home and abroad mainly involves the influence of tennis on athletes and the physical and mental health problems of college students, among which the influence of tennis mainly includes the impact on the body and psychology, and the physical and mental health problems of college students are mainly related to lifestyle and physique. The research less involves the influence of tennis on College Students' physical and mental health problems, so this study on the impact of tennis on College Students' physical and mental health.

\section{Physical and mental health evaluation of college students by tennis}

\section{Health evaluation of College Students}

Cardiopulmonary function is the most important index to measure the physical condition of a person. Meanwhile, heart rate and vital capacity are the most important indexes to measure the cardiopulmonary function. Heart rate and cardiopulmonary function are closely related to oxygen supply. Generally speaking, tennis is based on anaerobic oxidation energy, but in the test process of this study, the tennis training intensity of middle school students is not big, so the tennis training is mainly aerobic. Through the analysis of the relevant test results of students, the test results of various indexes of cardiopulmonary function of students before and after taking part in tennis are shown in the Table 1.

Table 1 shows the cardiopulmonary function test results of the students tested. It can be seen from the table that, in terms of heart rate at rest, the heart rate of boys is lower than that of girls, and the heart rate of boys and girls after training has decreased; in terms of vital capacity, the lung capacity of boys is smaller than that of girls, and the vital capacity of boys and girls after training is reduced. This shows that tennis can reduce the heart rate of students, which is mainly due to good exercise and exercise to reduce the sympathetic nerve excitability of students, and then reduce the myocardial oxygen consumption. In tennis 1 exercise, the muscle's oxygen demand increases, which makes the students' respiratory rate faster, and then makes the lung ventilation energy supply increase. Generally speaking, tennis is beneficial to enhance the students' cardiopulmonary function. The results of muscle strength test are shown in Table 2.

Table 2 shows the muscle strength test results of students' tennis training. The test results are divided into pre test and post test. The test items include back strength, left hand grip strength, right hand grip strength and the difference between left and right hand grip strength. From the table, it can be seen that, whether before or after training, the indexes for measuring muscle strength of boys are much larger than those of girls, and the range of changes of various indexes of boys is also larger. In addition, no matter boys or girls, after training, the indexes to measure muscle strength have increased. The left hand grip strength of male and female students before tennis training is smaller than that of right hand grip strength, and the range of change is also small. After training, the right hand grip strength of students has increased significantly, but the change of left and right grip strength is not obvious. In the process of tennis training, most of the students are used to hitting tennis with their right hand, which makes the right hand grip strength increase significantly after training, but the change of left and right grip strength is not obvious. Therefore, tennis is conducive to enhance the muscle strength of college students.

\section{Mental health evaluation of College Students}

In addition, in order to understand the influence of tennis on students' mental health, the personality independence of students is obtained according to the questionnaire, as shown in the Table 3.

Table 3 shows the scores of students' self-supporting personality according to the questionnaire. The students are divided into tennis training and non tennis training. The six indicators are interpersonal independence, interpersonal initiative, interpersonal flexibility, personal independence, personal initiative and personal flexibility. The full score of each index is 10 points. The results show that the maximum score, minimum score and average score are statistically significant. It can be seen from the table that the maximum, minimum and average scores of the six indexes of the students who choose tennis are basically greater

Table 1. Cardiopulmonary function test results.

\begin{tabular}{c|c|c|c}
\hline Gender & Test items & Male & Female \\
\hline Before training & Quiet heart rate (times) & $71.12 \pm 6.13$ & $75.57 \pm 6.46$ \\
\hline$/$ & Vital capacity $(I)$ & $3.68 \pm 0.46$ & $2.58 \pm 0.45$ \\
\hline After training & Quiet heart rate (times) & $70.47 \pm 5.71$ & $74.78 \pm 6.12$ \\
\hline$/$ & Vital capacity $(I)$ & $3.98 \pm 0.38$ & $2.74 \pm 0.41$ \\
\hline
\end{tabular}

Table 2. Student muscle strength test results.

\begin{tabular}{c|c|c|c}
\hline Gender & Training content & Male & Female \\
\hline Before training & Back force $(\mathrm{kg})$ & $95.21 \pm 19.15$ & $64.72 \pm 11.08$ \\
\hline$/$ & Left hand grip $(\mathrm{kg})$ & $37.21 \pm 5.29$ & $23.28 \pm 3.16$ \\
\hline$/$ & Right hand grip $(\mathrm{kg})$ & $39.76 \pm 6.51$ & $25.41 \pm 3.23$ \\
\hline$/$ & $\begin{array}{l}\text { Poor grip strength between } \\
\text { left and right hands }(\mathrm{kg})\end{array}$ & $2.55 \pm 1.49$ & $2.13 \pm 1.27$ \\
\hline After training & Back force $(\mathrm{kg})$ & $101.22 \pm 15.8$ & $68.76 \pm 9.37$ \\
\hline$/$ & Left hand grip $(\mathrm{kg})$ & $37.73 \pm 5.32$ & $23.62 \pm 3.28$ \\
\hline$/$ & Right hand grip $(\mathrm{kg})$ & 43.135 .96 & $27.84 \pm 3.06$ \\
\hline$/$ & $\begin{array}{c}\text { Poor grip strength between } \\
\text { left and right hands }(\mathrm{kg})\end{array}$ & 5.401 .34 & $4.22 \pm 1.42$ \\
\hline
\end{tabular}




\begin{tabular}{|c|c|c|c|c|c|c|c|c|c|}
\hline \multicolumn{5}{|c|}{ Elective tennis } & \multicolumn{5}{|c|}{ No elective tennis } \\
\hline Index & Number of people & Max & Min & Mean & Index & Number of people & Max & Min & Mean \\
\hline Interpersonal independence & 100 & 8.7 & 5.6 & 7.8 & Interpersonal independence & 100 & 7.9 & 4.3 & 5.8 \\
\hline Man-machine flexibility & 100 & 8.5 & 5.0 & 7.0 & Man-machine flexibility & 100 & 8.0 & 5.0 & 6.0 \\
\hline Interpersonal initiative & 100 & 9.0 & 4.8 & 7.3 & Interpersonal initiative & 100 & 7.4 & 4.6 & 5.6 \\
\hline Individual independence & 100 & 8.8 & 5.3 & 7.4 & Individual independence & 100 & 7.6 & 5.2 & 6.5 \\
\hline Personal flexibility & 100 & 8.6 & 6.4 & 8.2 & Personal flexibility & 100 & 8.0 & 4.8 & 5.2 \\
\hline Personal initiative & 100 & 9.2 & 5.8 & 7.7 & Personal initiative & 100 & 7.8 & 4.6 & 5.0 \\
\hline
\end{tabular}

than those of the students who do not. Moreover, the average scores of the students who choose tennis are more than 7 points. It shows that participating in tennis is conducive to cultivating the independent personality of college students, and is conducive to the mental health of students. It is also helpful for college students to be independent and flexible Live and take the initiative. Similarly, as shown in Figure 1 , the scores of depression between college students who participated in tennis and those who did not participate in tennis were compared. ${ }^{5}$

Figure 1 shows the depression scores of tennis players and non tennis players. The higher the score, the stronger the depression tendency. It can be seen from the figure that the number of students who did not choose tennis in the 15-20 score range and between 10-15 divisions were more than those who chose tennis, while the number of students who chose tennis in the 5-10 score range and between 0-5 division were more than those who did not It shows that compared with the students who choose tennis, the college students who do not choose tennis have relatively serious depression tendency, mainly manifested as psychomotor retardation,

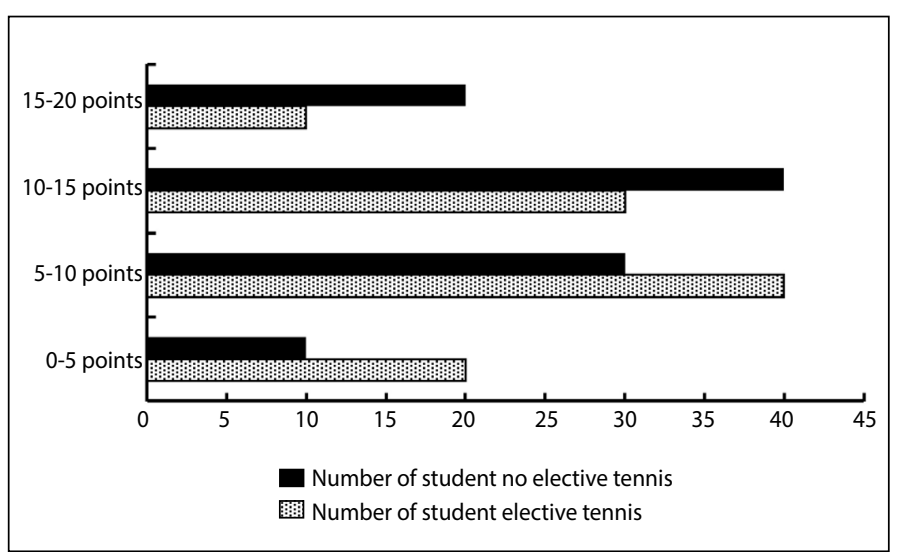

Figure 1. Comparison of depression scores of college students who participated in tennis and those who did not. feeling full of guilt and worthlessness, depression, loss of appetite, often feeling helpless and hopeless, and difficult to sleep. Combined with the scores of independent personality and depression tendency, it shows that tennis is beneficial to students' mental health. ${ }^{3}$

\section{CONCLUSIONS}

College students to participate in tennis are not only conducive to their physical health, but also conducive to their mental health. In order to understand the influence mechanism of tennis on College Students' physical and mental health, this study analyzes the influence of tennis on College Students' physical and mental health exercise. This research mainly uses the measurement method, literature method, questionnaire method and mathematical statistics method to study the situation of College Students' participation in tennis, and constructs the evaluation index of College Students' physical and mental health. The results show that college students' participation in tennis has a positive impact on their physical and mental health. Tennis can reduce the heart rate of college students, which is conducive to enhance the cardiopulmonary function of college students. At the same time, tennis can enhance the muscle strength of college students. The influence of tennis on the mental health of college students is mainly reflected in that tennis can help students develop independent personality, be independent, flexible and active, reduce depression tendency, and is conducive to the development of students' mental health.

\section{ACKNOWLEDGEMENTS}

The study was supported by the 2018 Basic Ability Improvement Project for Young and Middle-aged Teachers in Guangxi Universities -Research and Practice on the promotion of self media to college students' extracurricular sports activities (NO. 2018KY0650).

The author declare no potential conflict of interest related to this article

AUTHORS' CONTRIBUTIONS: The study was supported by the 2018 Basic Ability Improvement Project for Young and Middle-aged Teachers in Guangxi Universities -Research and Practice on the promotion of self media to college students' extracurricular sports activities (NO. 2018KY0650).

\section{REFERENCES}

1. Allen T, Choppin S, Knudson D. A review of tennis racket performance parameters. Sports Engineering. 2016; 19(1):1-11.

2. Ahmadpoor $P$, Rostaing $L$. Why the immune system fails to mount an adaptive immune response to a COVID-19 infection. Transpl Int. 2020; 33(7):824-5.

3. Pluim BM, Loeffen FGJ, Clarsen B, Bahr R, Verhagen EALM. A one-season prospective study of injuries and illness in elite junior tennis. Scandinavian Journal of Medicine \& Science in Sports. 2016; 26(5):564-571
4. Kwan MY, Arbour-Nicitopoulos KP, Duku E, Faulkner G. Patterns of multiple health risk-behaviours in university students and their association with mental health: application of latent class analysis. Health Promot Chronic Dis Prev Can. 2016; 36(8):163-170.

5. Fernandez-Fernandez J, Boullosa DA, Sanz D, Abreu L, Filaire E, Mendez-Villanueva A. Psychophysiological Stress Responses during Training and Competition in Young Female Competitive Tennis Players. International Journal of Sports Medicine. 2015; 36(01):22-28. 